3. Философский словарь / под ред. И. Фролова. Москва : Изд-во политической литературы, 1987. $590 \mathrm{c}$.

4. Сорока К. Основи теорії систем і системного аналізу : навчальний посібник. Харків : ХНАМГ, 2004. $291 \mathrm{c}$.

5. Горбань О., Бахрушин В. Основи теорії систем і системного аналізу : навчальний посібник. Запоріжжя : ГУ «ЗІДМУ», 2004. 204 с.

6. Спицнандель В. Основы системного анализа : учебное пособие. Санкт-Петербург : Изд. дом «Бизнесс-пресса», 2000. 326 с.

7. Мірошниченко М. До питання «вузького» та «широкого» розуміння правової системи. Журнал східноєвропейського права. 2014. № 10. С. 12-17.

8. Керимов Д. Методологические функции философии права. Государство и право. 1995. № 9. С. 15-22. $164 \mathrm{c}$

9. Сетров М. Основы функциональной теории организации. Ленинград : Наука, 1972.

10. Хаустова М. Національна правова система за умов розбудови правової демократичної державності в Україні : монографія. Харків : Право, 2008. 160 с.

11. Керимов Д. Методология права. Предмет, функции, проблемы философии права. Москва : Аванта +, 2001. 559 с.

12. Луць Л. До питання поняття «правова система суспільства» та його місце серед інших правових понять. Проблема законності : республіканський міжвідомчий науковий збірник. Вип 55. Харків : Національна юридична академія України, 2002. С. 15-24.

13. Огаренко Т. Структура та функції правової системи. Підприємництво, господарство і право. 2013. № 5. С. 12-15.

14. Міхайліна Т. Правосвідомість як відносно незалежний елемент правової системи. Актуальні проблеми держави і права. 2017. № 79. С. 15-19.

15. Міхайліна Т. Синергетична роль правосвідомості. Economic and law paradigm of modern society. 2016. № 1. C. 305-309.

САРКІСЯН В. М., аспірант кафедри державно-правових дисциплін (Луганський державний університет внутрішніх страв імені Е. О. Дідоренка)

УДК 343.9

DOI https://doi.org/10.32842/2078-3736-2019-6-1-12

\title{
КОНСТИТУЦЙНО-ПРАВОВІ ЗАСАДИ ЗДІЙСНЕННЯ ГРОМАДСЬКОГО КОНТРОЛЮ ЗА ДІЯЛЬНІСТЮ НАЦІОНАЛЬНОЇ ПОЛІЦІЇ ПІД ЧАС ПРОВЕДЕННЯ ВИБОРІВ В УКРАЇНІ
}

У статті розкрито конституційно-правові засади здійснення громадського контролю за діяльністю Національної поліції під час проведення виборів в Україні. Зазначено, що Національна поліція відіграє вкрай важливу роль у проведенні демократичних і чесних виборів в Україні. Тому цілком виправданою $є$ практика здійснення громадського контролю за діяльністю Національної поліції під час проведення виборів в Україні з метою унеможливлення іiі використання в політичних цілях і вчинення фальсифікації виборів. Запропо-

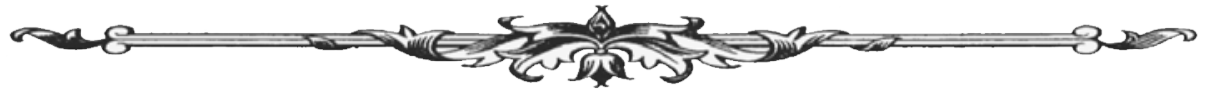


новано визначення громадського контролю за діяльністю Національної поліції під час проведення виборів в Україні. Розглянуто мету та завдання громадського контролю за діяльністю Національної поліції під час проведення виборів в Україні. Проаналізовані форми проведення громадського контролю за діяльністю Національної поліції під час проведення виборів в Україні. Зосереджено увагу на конституційно-правовій формі проведення громадського контролю за діяльністю Національної поліції під час проведення виборів в Україні. Розкриті методи здійснення громадського контролю за діяльністю Національної поліції під час проведення виборів в Україні. Окреслено коло суб'єктів, на які покладено завдання проведення громадського контролю за діяльністю Національної поліції під час проведення виборів в Україні. Встановлено значення громадського контролю за діяльністю Національної поліції під час проведення виборів в Україні. Зроблено висновок, що здійснення громадського контролю за діяльністю Національної поліції під час проведення виборів в Україні $є$ важливою та затребуваною конституційно-правовою формою участі громадськості у вирішенні державних і суспільних справ. Визначені перспективні напрями вдосконалення процесу проведення громадського контролю за діяльністю Національної поліції під час проведення виборів в Україні. Відносини Національної поліції та громадськості під час проведення виборів в Україні повинні мати партнерський характер, а не вибудовуватися на антагоністичних засадах, за яких Національна поліція та громадськість $€$ непримиренними суперниками.

Ключові слова: конституиійно-правові засади, громадський контроль, громадськість, Національна полічія, вибори, Украӥна.

The article describes the constitutional and legal principles of public control over the activities of the National Police during the elections in Ukraine. It is stated that the National Police plays an extremely important role in holding democratic and fair elections in Ukraine. Therefore, the practice of exercising public control over the activities of the National Police during elections in Ukraine in order to prevent its use for political purposes and to falsify elections is quite justified. The decision of public inspection is offered after activity of the National police during realization of elections in Ukraine. An aim and task of public inspection are considered after activity of the National police during realization of elections in Ukraine. Analyzed forms of realization of public inspection after activity of the National police during realization of elections in Ukraine. Attention is concentrated on the constitutionally-legal form of realization of public inspection after activity of the National police during realization of elections in Ukraine. Exposed methods of realization of public inspection after activity of the National police during realization of elections in Ukraine. The circle of subjects is outlined, on that the task of realization of public inspection is fixed after activity of the National police during realization of elections in Ukraine. The value of public inspection is set after activity of the National police during realization of elections in Ukraine. It is concluded that exercising public control over the activities of the National Police during elections in Ukraine is an important and required constitutional and legal form of public participation in the resolution of state and public affairs. Certain perspective directions of improvement of process of realization of public inspection after activity of the National police during realization of elections in Ukraine. The relations between the National Police and the public during the elections in Ukraine should be of a partnership nature, and not be based on antagonistic foundations, for which the National Police and the public are unrelenting rivals.

Key words: constitutional and legal framework, public control, public, National police, elections, Ukraine.

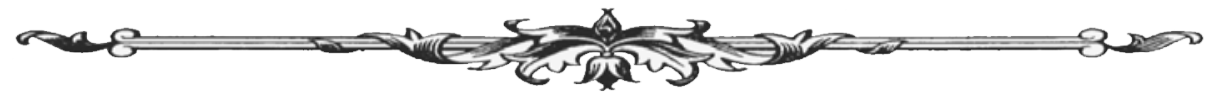


Вступ. Здійснення громадського контролю за владою є особливим видом соціального контролю, якому із посиленням демократичних механізмів участі громадськості у вирішенні державних та суспільних справ відведено помітне місце в діяльності органів публічної влади в Україні. Однак у вітчизняній юридичній літературі щодо цього слушно зауважується, що «громадський контроль не є досконалим механізмом контролю над владою, оскільки такий контроль зазвичай не має юридично-владного змісту, а рішення за результатами його здійснення мають зазвичай рекомендаційний характер» [3, с. 300]. Попри зазначену вище думку, конституційно-правові форми громадського контролю за владою, а особливо за правоохоронними органами, все активніше набувають різноманітного та законодавчо врегульованого характеру в Україні.

Питання правових засад здійснення громадського контролю за діяльністю органів публічної влади в Україні відображено у працях таких учених, як: Л. Гапоненко [1], I. Журавська [2], В. Кравчук [3], С. Кушнір [4; 5], О. Музичук [6], Т. Наливайко [7], В. Нестерович [8-10], Л. Рогатіна [11], О. Скрипнюк [12], В. Федоренко [12] та ін. Водночас, попри грунтовні наукові праці зазначених учених, питання конституційно-правових засад здійснення громадського контролю за діяльністю Національної поліції під час проведення виборів в Україні так і було грунтовно досліджено у вітчизняній юридичній науці.

Постановка завдання. Метою статті є розкриття конституційно-правових засад здійснення громадського контролю за діяльністю Національної поліції під час проведення виборів в Україні.

Результати дослідження. Національна поліція відіграє вкрай важливу роль у проведенні демократичних і чесних виборів в Україні. Ключовими складниками цього є передусім політична нейтральність роботи поліції, законність і ефективна взаємодія із громадськістю. Саме на поліцію покладається завдання гарантування публічної безпеки і порядку під час проведення виборів в Україні, а також охорона виборчих та суміжних прав і свобод людини під час виборчого процесу. Тому цілком виправданою є практика здійснення громадського контролю за діяльністю Національної поліції під час проведення виборів в Україні $з$ метою унеможливлення іiі використання в політичних цілях та вчинення фальсифікації виборів. Окрім цього, усе помітніше співробітники Національної поліції висувають свої кандидатури для участі у виборах народних депутатів України й особливо місцевих виборах без переривання своєї службової діяльності в Національній поліції на час здійснення виборчого процесу.

Здійснення громадського контролю за діяльністю Національної поліції під час проведення виборів в Україні має такі цілі:

- по-перше, забезпечити політичну нейтральність діяльності Національної поліції унеможливленням іiї втягнення у виборчу боротьбу на боці певного кандидата або політичної партії, які беруть участь у виборах;

- по-друге, не допустити використання співробітниками Національної поліції, які балотуються на виборах в Україні, свого службового становища на власну користь під час виборчого процесу;

- по-третє, сприяти поінформованості Національної поліції про виявлені громадськістю факти порушень виборчого законодавства України та більш активного й об'єктивного реагування поліції на ці порушення;

- по-четверте, посилити прозорість, відкритість та підзвітність Національній поліції під час проведення виборів в Україні перед суспільством;

- по-п’яте, підвищити професійність співробітників Національної поліції під час проведення виборів в Україні;

- по-шосте, дати об'єктивну оцінку діяльності Національній поліції під час проведення виборів в Україні та проінформувати про неї суспільство.

Здійснення громадського контролю за діяльністю Національної поліції під час проведення виборів в Україні регулюється Конституцією України, Кодексом України про адміністративні правопорушення та законами України «Про звернення громадян» № 393/96-ВР

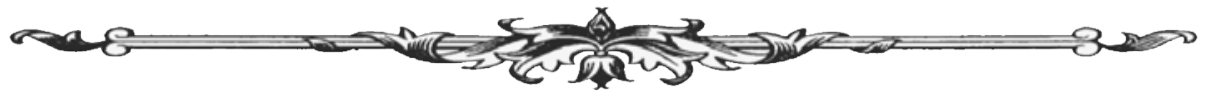


від 2 жовтня 1996 р., «Про інформацію» № 2657-XII від 2 жовтня 1992 р., «Про доступ до публічної інформації» № 2939-VI від 13 січня 2011 р., «Про громадські об’єднання» № 4572-VI від 22 березня 2012 р., «Про Національну поліцію» № 580-VIII від 2 липня 2015 р., «Про вибори Президента України» № 474-XIV від 5 березня 1999 р., «Про вибори народних депутатів України» № 4061-VI від 17 листопада 2011 р., «Про місцеві вибори» № 595-VIII від 14 липня 2015 р., «Про Центральну виборчу комісію» № 1932-IV від 30 червня 2004 р. та «Про Державний реєстр виборців» № 698-V від 22 лютого 2007 р.

Виборче законодавство України досить детально регулює діяльність поліції під час виборчого процесу. Це зумовлено тим, що від професійності та політичної нейтральності поліції великою мірою залежить проведення демократичних та чесних виборів. Відповідно до виборчого законодавства України, Національна поліція організовує свою роботу під час виборчого процесу, зокрема у вихідні дні та в день голосування, таким чином, щоби забезпечити прийом і розгляд документів щодо підготовки та проведення виборів, позовних заяв, скарг і звернень виборчих комісій у строки та спосіб, установлені виборчим законодавством України. У разі вчинення правопорушень, за які законом встановлена відповідальність, голова або заступник голови дільничної виборчої комісії мають право запросити у приміщення для голосування поліцейського, який повинен вжити до порушника передбачених законом заходів і залишити приміщення для голосування. Перебування поліцейських у приміщенні для голосування в інших випадках забороняється [13-15].

Заборона щодо перебування поліцейських у приміщенні для голосування $є$ загальновизнаним міжнародним стандартом, на який окремо вказано у деяких міжнародних документах. Наприклад, у п. 132 Доповіді про виборче законодавство та виборчу адміністрацію в Свропі 2004 р. зазначається, що «поліція та сили безпеки зазвичай не повинні знаходитися усередині (або навіть зовні) приміщення виборчої дільниці, оскільки це може лякати виборців, особливо в державах із слабкими демократичними традиціями або у постконфліктних ситуаціях. Поліції зазвичай дозволено заходити у приміщення виборчої дільниці на прохання голови відповідної виборчої комісії для підтримання порядку. Представників поліції запрошують лише тоді, коли ситуація може вийти 3-під контролю». Також у п. 132 цієї Доповіді конкретизується, що «у певних випадках виборче законодавство або інструкції, надані Центральною виборчою комісією, повинні встановлювати більш чіткі положення щодо присутності поліцейських у приміщеннях для голосування та їхньої ролі в день виборів» [16, с. 29].

На поліцію, згідно з виборчим законодавством України, під час проведення виборів в Україні покладається: 1) постійна охорона сейфів (металевих шаф або окремих кімнат) окружної виборчої комісії до передачі виборчих бюлетенів дільничним виборчим комісіям; 2) охорона транспортування членами дільничної виборчої комісії звичайних і спеціальних виборчих дільниць (крім дільниць на суднах, що перебувають на цей час у плаванні під державним прапором України, та на полярній станції України) отриманих ними виборчих бюлетенів до приміщення дільничної виборчої комісії; 3) постійна охорона виборчих бюлетенів, які зберігаються у приміщенні дільничної виборчої комісії в сейфі (металевій шафі) до початку підготовчого засідання комісії; 4) протидія порушенням виборчого законодавства України у день голосування на виборах, а у випадку їх вчинення документування фактів протиправної поведінки; 5) охорона транспортування членами дільничної виборчої комісії виборчих документів після підрахунку голосів виборців на виборчій дільниці [13-15].

Одним із ключових моментів у проведенні реформи поліції в Україні $є$ посилення ролі громадського контролю в діяльності поліції. Наочним підтвердженням цьому є суттєве приділення уваги взаємодії поліції та громадськості в Законі України «Про Національну поліцію» від 2 липня 2015 р. № 580-VIII. Зокрема, у цьому Законі встановлюються такі засади громадського контролю в діяльності поліції:

1) поліція здійснює свою діяльність на засадах відкритості та прозорості в межах, визначених Конституцією та законами України (ч. 1 ст. 9);

2) поліція забезпечує постійне інформування органів державної влади та органів місцевого самоврядування, а також громадськості про свою діяльність у сфері охорони та

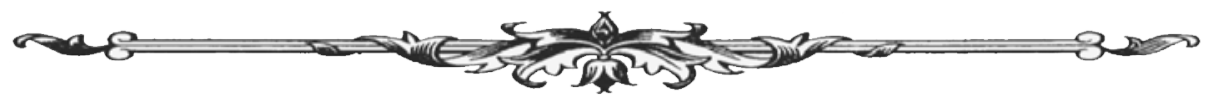


захисту прав і свобод людини, протидії злочинності, забезпечення публічної безпеки і порядку (ч. 2 ст. 9);

3) проєкти нормативно-правових актів, що стосуються прав та свобод людини, обов’язково проходять громадське обговорення в порядку, визначеному міністром внутрішніх справ України (ч. 6 ст. 9);

4) поліція у своїй діяльності є незалежною від рішень, заяв чи позицій політичних партій та громадських об'єднань (ч. 2 ст. 10);

5) діяльність поліції здійснюється в тісній співпраці та взаємодії з населенням, територіальними громадами та громадськими об’єднаннями на засадах партнерства і спрямована на задоволення їхніх потреб (ч. 1 ст. 11);

5) до складу поліцейської комісії апарату центрального органу управління поліції із числа п’яти осіб входять два представники громадськості, рекомендовані Уповноваженим Верховної Ради України з прав людини, з числа осіб, які мають бездоганну репутацію, високі професійні та моральні якості, суспільний авторитет (п. 3 ч. 2 ст. 51);

6) до складу поліцейської комісії апарату центрального органу управління поліції із числа п’яти осіб входять два представники громадськості, обрані відповідною обласною радою, Верховною Радою Автономної Республіки Крим, Київською міською радою, Севастопольською міською радою із числа осіб, які мають бездоганну репутацію, високі професійні та моральні якості, суспільний авторитет (п. 4 ч. 3 ст. 51);

7) 3 метою інформування громадськості про діяльність поліції керівник поліції та керівники територіальних органів поліції раз на рік готують та опубліковують на офіційних вебпорталах органів поліції звіт про діяльність поліції (ч. 1 ст. 86);

8) керівники територіальних органів поліції з метою підвищення авторитету та довіри населення до поліції систематично інформують громадськість про стан правопорядку, заходи, які вживаються щодо попередження правопорушень (ч. 2 ст. 88);

9) поліція взаємодіє із громадськістю шляхом підготовки та виконання спільних проєктів, програм і заходів для задоволення потреб населення та покращення ефективності виконання поліцією покладених на неї завдань (ч. 1 ст. 89);

10) співпраця між поліцією та громадськістю спрямована на виявлення й усунення проблем, пов'язаних зі здійсненням поліцейської діяльності, і сприяння застосуванню сучасних методів для підвищення результативності й ефективності здійснення такої діяльності (ч. 2 ст. 89);

11) поліція надає підтримку програмам правового виховання, пропагує правові знання в освітніх закладах, засобах масової інформації та у видавничій діяльності (ч. 3 ст. 89);

12) контроль за діяльністю поліції може здійснюватися у формі залучення представників громадськості до спільного розгляду скарг на дії чи бездіяльність поліцейських та до перевірки інформації про належне виконання покладених на них обов'язків відповідно до законів та інших нормативно-правових актів України (ч. 1 ст. 90) [17].

Водночас у Законі України «Про Національну поліцію» наводяться загальні засади здійснення громадського контролю за Національною поліцією, здійснення ж громадського контролю за діяльністю Національної поліції під час проведення виборів в Україні має специфічний характер. До сутнісних рис здійснення громадського контролю за діяльністю Національної поліції під час проведення виборів в Україні варто віднести такі: 1) здійснення громадського контролю за діяльністю Національної поліції під час проведення виборів в Україні обмежено чіткими строками здійснення виборчого процесу; 2) громадський контроль за діяльністю Національної поліції під час проведення виборів в Україні обмежений лише питаннями, що стосуються порядку підготовки та проведення виборів; 3) особливий суб' єктний склад громадського контролю за діяльністю Національної поліції під час проведення виборів в Україні, який обумовлений специфікою суб' єктів виборчого процесу (виборці, кандидати, офіційні спостерігачі від громадських організацій, до статутної діяльності яких належать питання виборчого процесу та спостереження за ним); 4) політизованість виборчих правовідносин певною мірою позначається і на політизації

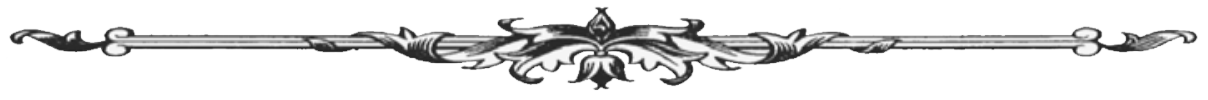


форм і методів громадського контролю за діяльністю Національної поліції під час проведення виборів.

Здійснення громадського контролю за Національною поліцією під час проведення виборів в Україні все помітніше грунтується на використанні громадськістю сучасних інформаційних технологій і електронних ресурсів. Соціальні мережі, месенджери, електронні петиції, електронні опитування, розміщення та поширення політичної реклами на відеохостингах, проведення виборчої кампанії кандидатами та політичними партіями в мережі Інтернет - усе це є неодмінною ознакою сучасних демократичних і конкурентних виборів, отже, і важливою джерельною базою в рамках здійснення громадського контролю за Національною поліцією під час проведення виборів в Україні.

Суттєво полегшує здійснення громадського контролю за діяльністю Національної поліції під час проведення виборів в Україні відкритість та прозорість діяльності поліції, а також доступність для громадськості різного роду реєстрів та інформаційних ресурсів, розпорядником яких є Національна поліція та Міністерство внутрішніх справ України. Як позитивний приклад підвищення прозорості діяльності Національної поліції під час проведення виборів в Україні варто назвати введення в дію на передодні чергових виборів Президента України 2019 р. інформаційно-аналітичної системи «Вибори-2019». Зазначена система $\epsilon$ геоінформаційним аналітичним порталом Міністерства внутрішніх справ (далі - MBC) України, який призначений для моніторингу здійснення правопорушень для відображення публічної інформації про стан громадської безпеки. Портал МВС дає можливість: 1. На базі геоінформаційної системи вести моніторинг у режимі реального часу здійснених правопорушень виборчого процесу, як-от: адміністративні правопорушення виборчого законодавства; кримінальні правопорушення виборчого законодавства; некласифіковані порушення виборчого законодавства; інші події, що порушують виборчий процес. 2. Оприлюднення та візуалізації деперсоніфікованих подій [18].

За здійснення громадського контролю за діяльністю Національної поліції під час проведення виборів в Україні громадськість найбільше цікавлять такі питання: 1) стан готовності Національної поліції до гарантування публічної безпеки і порядку під час проведення виборів в Україні; 2) загальний стан криміногенної обстановки під час проведення виборів в Україні; 3) кількість звернень, які надійшли до органів Національної поліції щодо порушень виборчого законодавства України, та результати їх розгляду; 4) кількість і характер порушень виборчого законодавства України, які були виявлені співробітниками Національної поліції; 5) заходи, яких ужито або яких буде вжито для недопущення порушень виборчого законодавства України; 5) стан реагування керівництва Національної поліції щодо скарг на протиправні дії або бездіяльність поліцейських під час проведення виборів в Україні.

Загалом міжнародними та національними спостерігачами, які працювали в Україні на президентських і парламентських виборах у 2019 р., високо оцінено діяльність Національної поліції, іiї політичну нейтральність та професійність. Наприклад, у Звіті за результатами спостереження Громадянської мережі «Опора» на позачергових виборах народних депутатів України 21 липня 2019 р. «Тенденції липня та попередні висновки кампанії» зазначено, що відповідно до методології спостереження «Опори», спостерігачі не лише фіксують і верифікують порушення, а й офіційно звертаються до Національної поліції України з метою розслідування випадків недотримання законодавства. 3 початку виборчого процесу спостерігачами «Опори» подано 882 звернення до Національної поліції (частина з них включала повідомлення про більше ніж одне порушення) щодо виявлення ознак порушення виборчого законодавства. За оцінками організації, співробітники Національної поліції України зазвичай реагували належним чином на іiі повідомлення про порушення правил ведення передвиборної агітації. Навіть більше, представники «Опори» безпосередньо не виявили підтверджених фактів грошового підкупу громадян, але з офіційних джерел відомо про розслідування Національною поліцією України 62 проваджень щодо такого різновиду підкупу [19].

Висновки. Отже, здійснення громадського контролю за діяльністю Національної поліції під час проведення виборів в Україні є важливою та затребуваною конституційно-

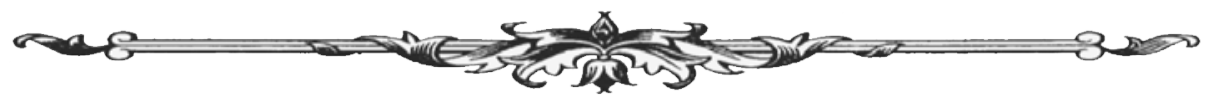


правовою формою участі громадськості у вирішенні державних та суспільних справ. Відносини Національної поліції та громадськості під час проведення виборів в Україні повинні мати партнерський характер, а не вибудовуватися на антагоністичних засадах, за яких Національна поліція та громадськість є непримиреними суперниками.

\section{Список використаних джерел:}

1. Гапоненко Л. Громадський контроль за діяльністю органів виконавчої влади: сутність та механізм реалізації. Юридичний науковий електронний журнал. 2015. № 4. С. $43-47$.

2. Журавська I. Громадський контроль як інтегральна складова у концепті владних відносин сучасної держави і громадянського суспільства. Часопис Київського університету права. 2012. № 3. С. 14-17.

3. Музичук О. Контроль за діяльністю правоохоронних органів в Україні : монографія. Харків : ХНУВС, 2010. 564 с.

4. Кравчук В. Нормативно-правове забезпечення громадського контролю в Україні. Публічне право. 2016. № 2. С. 300-306.

5. Кушнір С. Правові засоби громадського контролю в механізмі правового регулювання : автореф. дис. ... канд. юрид. наук: 12.00.01. Запоріжжя, 2011. 20 с.

6. Кушнір С. Громадський контроль за діяльністю органів внутрішніх справ в Україні. Вісник Запорізького національного університету. Серія «Юридичні науки». 2013. № 1. C. 9-15.

7. Наливайко Т. Громадський контроль в Україні як інститут громадянського суспільства: теоретико-правовий аспект : автореф. дис. ... канд. юрид. наук: 12.00.01. Львів, 2010. 18 с.

8. Нестерович В. Конституційно-правові засади впливу громадськості на прийняття нормативно-правових актів: зарубіжний та український досвід : дис. ... докт. юрид. наук: 12.00.02. Суми, 2015. 456 с.

9. Нестерович В. Інституційне утвердження електронних петицій в Україні у контексті зарубіжного досвіду. Віче. 2015. № 22. С. 18-23.

10.Нестерович В. Практикум з Конституційного права України. Київ : Ліра-К, 2018. $640 \mathrm{c}$.

11. Рогатіна Л. Громадський контроль над державою: сутність, механізми реалізації та перспективи розвитку : автореф. дис. ... канд. політ. наук: 23.00.02. Одеса, 2011. 17 с.

12.Нормотворча діяльність Президента України та її нормопроєктне забезпечення : монографія / О. Скрипнюк та ін. ; за ред. О. Скрипнюка, В. Федоренка. Київ : НАДУ, 2011. $344 \mathrm{c}$.

13.Про вибори Президента України : Закон України від 5 березня 1999 р. № 474-XIV. Відомості Верховної Ради України. 1999. № 14. Ст. 81.

14.Про вибори народних депутатів України : Закон України від 17 листопада 2011 р. № 4061-VI. Відомості Верховної Ради України. 2012. № 10. Ст. 73.

15.Про місцеві вибори : Закон України від 14 липня 2015 р. № 595-VIII. Відомості Верховної Ради Украӥни. 2015. № № 37-38. Ст. 366.

16. Report on electoral law and electoral administration in Europe. Synthesis study on recurrent challenges and problematic issues (CDL-AD (2006) 018): Adopted by the Council for Democratic Elections and the Venice Commission. Strasbourg, 2006. 51 p.

17.Про Національну поліцію : Закон України від 2 липня 2015 р. № 580-VIII. Відомості Верховної Ради Украӥни. 2015. № № 40-41. Ст. 379.

18.Інформаційно-аналітична система «Вибори-2019». URL: https://mvs.gov.ua/ua/ pages/5496_Informaciyno_analitichna_sistema_Vibori_201.htm.

19.Звіт за результатами спостереження Громадянської мережи «Опора» на позачергових виборах народних депутатів України 21 липня 2019 р. «Тенденції липня та попередні висновки кампанії». URL: https://bit.ly/3494WIU.

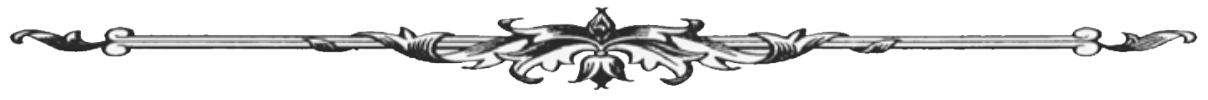

